\title{
Research and the Practice on the "2+1+1" Accounting Talent Development Mode
}

\author{
Heping CHEN \& Fang MA \\ School of Management, Southwest University of Political Science \& Law, Chongqing 401120, China
}

\begin{abstract}
The School of Management of Southwest University of Political Science \& Law has cooperated with Chongqing Heqin Firm to try out the "2+1+1" style-a new accounting talent development mode. It renewed the target of accounting talent development, integrated the curriculum system, established the diversified internship system and bases, employed some experienced specialists as teachers, advocated students' self-management, and proposed the concept of "forceful in practice, capable of management and adept at creativity", which reaped a satisfactory effect on teaching.
\end{abstract}

KEYWORD: University-enterprise cooperation; Accounting talent; Development mode

\section{THE CONNOTATION OF THE“ $2+1+1$ " MODE OF ACCOUNTANT TALENT}

\subsection{The Implication of the " $2+1+1$ " Mode of Accountant Talent}

The School of Management of Southwest University of Political Science \& Law has cooperated with Chongqing Heqin Firm to try out on accountant majors the " $2+1+1 "$ style-a new accounting talent development mode, in which students majoring in accountant are scheduled to finish the common required courses, the basic courses for business management majors and accountant majors within two years, and to finish the specialized courses and practice courses for accountant majors within one year to cultivate its advantages of professional skills and abilities, and to finish their comprehensive internship and diploma project so as to assist their formation of professionalism. Compared with the current education mode of accountant talent, the new one possess three advantages: forceful in practice, capable of management and adept at creativity, aiming at putting into practice the cultivation of abilities as well as the application.

\subsection{The Orientation of the " $2+1+1$ " Mode of Accountant Talent}

The fact that colleges at different levels share almost the same objectives of educating the accountant talent is to blame for the closeness of these objectives, resulting in the detachment of their objectives and the actual demands of the accountant talent and in the aimlessness of students' job hunting.

Therefore, the new mode of " $2+1+1$ " aims at the implement of college- enterprise cooperation, highlighting the comprehensive development of basic knowledge, ability and quality so as to provide the enterprise and public institution, judicial offices and agencies with accountant talents characterized at "forceful in practice, capable of management and adept at creativity."

Broadly speaking, applied talents include all the other talents besides those engaging in the originally academic research of basic theories. The applied talents has various levels and kinds. The education of applied accountant talents of undergraduate should focus on the harmonious development of knowledge, ability and quality. They should possess more professional knowledge and should be more adept in basic skills than vocational high schools and technical secondary schools. What's more, they should be better at self-study and be more adaptive at their posts so that they are qualified for the position of accountants and have better overall qualities of multiple management posts as well as professional judgment.

Compared with other kinds of talents, the accountant talents educated in the new mode should have better abilities of practice and operation, and should be able to quickly adapt themselves to the new post and to solve practical issues. The emphasis of the education of applied accountant talents of undergraduate should be laid on the training and 
development of the students' practical, communicative and problem-solving abilities.

In other words, the applied accountant talents of undergraduate will be the talents good at putting the theoretical knowledge into social practice, thus serving the market economy.

The accountant majors have not only solid theoretical knowledge of accountant, but also strong practical abilities as accountants. Meanwhile, they also have the abilities of prediction, decisionmaking, organization, management and directing business.

The applied accountant talents of undergraduate can keep accounts, cast accounts and submit expense accounts. They also should have total control of a complete financial accounting system. They should have solid theoretical backgrounds and making sound professional judgments, strong abilities of modern information processing, reorganization and analysis. They should familiarize themselves with relevant accounting laws, regulations, and legal norms. They should be very conscious of risks, control, manage and avoid risks of the business activities of the enterprise through strategic management, capital budgeting, risk control, working capital management, performance assessment, international investment decisionmaking, etc.

\section{THE PRACTICE OF THE“ $2+1+1$ ” MODE OF ACCOUNTANT TALENT}

In order to achieve the goal of the education of accountant talent, a college-enterprise practice platform and two college-enterprise fronts are required to be established, through which the university and corporation can share resources, the talent cultivating program meeting the need of various enterprises can be designed by both the school and the enterprise including professional orientation, the educational standard, curriculum structure, ratio of practice, practice content, etc. and through which the students can be taught by double teachers from both the school and the enterprise and can complete the teaching objectives.

\subsection{To Establish a Teaching System of General Knowledge, Specialized Knowledge and Occupational Abilities}

Relevant courses should be incorporated so that students can form a clear lifetime objective, a healthy personality and a full sense of responsibility for the society. They should have compacted professional backgrounds, wide-scope general knowledge, a strong desire to be creative, keen perception, self-development analysis, knowledgeshifting, corporation and decision-making abilities.
They also should have exquisite professional skills, broad vocational view and the abilities of finding and solving problems.

\subsection{To build up a Diversified Practical Teaching System and Practice Base}

The key to the education of the applied accountant talent is to build up a multi-channel teaching system. We have established a city-level practice base outside the campus and a simulation laboratory on the campus founded by the cooperative enterprise. We have also intensified the social practice, social research, professional internship, graduation paper, etc. moreover, we have incorporated relevant curriculums and raise the percentages of practice courses, which is $22.5 \%$ currently with 36 credits.

The School of Management has established a city-level practice base and employed a close cooperation mode--- the closeness of professional backgrounds, of materials, of business practice, and of teaching faculties. The "Heqin Accounting Laboratory" is co-established by the university, well-known financial software companies and Heqin Advisory Agency, and founded by Heqin Advisory Agency. The laboratory directly undertake its business of generation of account, which allows students to operate on all the basic business and procedures all-dimensionally.

\subsection{The Main Characteristics of College-enterprise Corporation}

\subsubsection{Sufficient Business}

We have directed students into the practice state, from the steps, material preparation and follow-up service, during the practice of "Heqin Accounting Laboratory", the acceptance of generation of account, the agency of industrial and commercial business, capital verification business, the accounting statement auditing, the audit of financial revenue and expenditure. The students' practice cycle is arranged by the university.

\subsubsection{The Characteristics of Double-teacher Mode}

The "double-teacher mode" is that students are taught simultaneously by a teacher teaching theories and the other practices. At the same time, they also are equipped with two instructors--- the "theory" instructor is responsible for the student's professional theories study and the "practice" instructor for his professional practice and social practice. The aim is to break through the traditionally mono practice teaching system, to add space for practice teaching, to combine professional theory study and social practice organically, and to combine the students' classroom training and real- 
time practice, through which the zero-distance cultivation of the applied talent is realized.

\subsubsection{The Characteristics of Real-time Practice}

A system of project management for the student is established and the student takes part in it, simulate and assist the project manager with the management, understands the process and risk-avoiding of project management. The curriculums of management are designed by the university, i.e. the theory comes after the practice, so as to cultivate the comprehensive talents for project management.

\section{CONCLUSIONS FROM THE STUDENTS}

\subsection{Excellent Construction of Study Style}

The construction of study style, as the eternal theme of the college, is the critical condition of the implement of the Party's education policy and the realization of education outstanding talents. Meanwhile, a positive study style can exert a subtle spiritual influence on students, which is great and invisible, stimulating students and improving them to grow healthily all the time. Over $90 \%$ of the students polled agree that this new mode can arouse their eagerness for study, such as:

\subsubsection{More Consciousness for study and Higher Class Attendance Rate}

The records of the disciplinary prefect of the experimental accounting class shows that the class attendance rate is $100 \%$ most of the times except for the occasion of some students asking for leave due to urgencies. Almost all the teachers of the situation and policy course of the experimental class speak highly of the class attendance, which is quite rare among other classes of the university. Additionally, the students of the experimental class are always zealous to teach themselves. They can be found at the self-access hall, at the library, and in Room 506 of Zhizhi Building. There are many students of the experimental class to teach themselves. They stay together in order to monitor each other, inspire each other, study together and make progress together.

\subsubsection{The Strong Self-motivation and Energy of the Students on Study}

The greatest difference between the experimental class and other classes is that they have more practice courses, which requires the students to have more chances to practice. The courses of "financial record analysis" and "combined financial statement design" require large workload compared with other courses, demanding the students to be not only very familiar with the knowledge in the textbook, but also patient and durable enough to handle multifarious numbers. However, the commissary in charge of studies of the experimental class says that the students are able to finish their assignment with high quality beforehand and never lag behind. They are also able to discuss actively with each other or consult the teacher about some confusing questions. These students say there is a positive competition among them and everybody can take their jobs seriously and do well. They compete with each other and help each other simultaneously.

\subsubsection{The Students' Great Interest and Positive Attitude in Studies}

The majority of the courses for the experimental class are lectured by the in-service staff of the enterprise and public institution, who lack experiences in teaching. Some of them give vague orneriness or their words even fail to convey their ideas in their lectures, making it rather hard for the students to catch up. The students, however, are not inattentive but still positive in their studies. They are tolerant with those teachers from outside the campus and consult the teachers of the university or other classmates, or they look for answers of difficult questions from reference books till they really understand.

The students, on the other hand, are able to deal with the more burdensome assignments compared with other regular classes. Many students state at the poll that many times they have to read and do their homework on weekends while students from the regular classes are watching movies or playing games, which arouses not their complaints but their consent for the great worth of studying--- a one-time pleasure is inferior to hard work.

\subsection{The Students' Extraordinary Scores}

\subsubsection{The Students' Extraordinary Academic Scores}

The terminal scores for the first term of the year 2013-2014 published by the office of teaching affairs demonstrate that the percentage of passing the terminal exams are $100 \%$ and the top score of the weighted average is 89.47417 , which is the top score among the classes of the accounting major. The lowest score is 74.95 , the average of the class is 83.30, and the excellent rate reaches $49 \%$, while the lowest score, the average and the excellent rate of the whole grade 2011 accounting majors are respectively $70.648,80.6725$ and $13.66 \%$.

\subsubsection{The Students' Excellent Achievement in Literary and Sport Competitions}

During the time of the year 2013 to 2014, the students of the experimental class participated actively in all kinds of literary and sport competitions and won excellent scores while 
finishing their academic studies. These students, according to the incomplete statistics, have received many university-level awards including the first prize of nationwide college simulative enterprise competition, the first prize and the second prize of national GMC, the excellent competitor for debate competition among China's universities of political science and laws, the second prize of the tennis match among universities in Chongqing, the first prize of women's doubles and third prize of women's single of college students' tennis match in Chongqing, the second prize of women's medley swimming and women's medley rally swimming of Chongqing college students' swimming sport.

Seven students from the experimental class have received, in the university competition of perfect persons, the honorary titles, such as "College Students of Merits", "College Students of Sports Star", "College Students of Excellence", "College Students Prefects", "College Students of Scientific and Technological Creation", etc.. These students of prize and honorary title winners account for $25 \%$ of the whole experimental class. There are also another seven students from the experimental class who have received the honorary title of "Advanced Persons" in the program of college students spreading scientific and literary knowledge and offering medical services to people in the rural area. What's more, many other students from the experimental class also received the honorary title of "Advance Persons of the School of Management".

In conclusion, the experimental class of the " $2+1+1$ " accounting talent education mode of the school of management sticks to the concept of "forceful in practice, capable of management and adept at creativity", summoning the students to endeavor to finish the studies with great eagerness and activeness, creating a strong atmosphere for class studies, thus assuring the students to gain excellent scores in all kinds of compulsory and practice courses. The study of practice courses enriches students' practical knowledge and to a large extent improves their abilities of practical operation. The ability of "forceful in practice" is increasingly becoming an ability these students really have. The students of the experimental class took part in all kinds of literary and sport competitions actively and reaped a lot form those activities like many honors for the school and the university while displaying their spirituality of making a difference and staying positive.

\section{REFERENCES}

[1] Ouyang, Aiping, 2010. The exploration and practice of the cultivation of accounting talent ---the setting and operation of full English teaching; Professional Accounting Education Committee of China Accounting Association.

[2] Chen, Hong, \&Yu Genya, \& Chen Yongfei, 2010. A Probe into the Education of Undergraduate Accounting Talent--- A Thought of the Cultivation of Composite Applied Talent of Yunan University of Finance and Economy, Professional Accounting Education Committee of China Accounting Association. 